\title{
A TUTELA DE EVIDÊNCIA NO NOVO CÓDIGO DE PROCESSO CIVIL
}

\section{THE EVIDENCE GUARDIANSHIP IN THE NEW CODE OF CIVIL PROCEDURE}

\section{Emiliane Scheidt ${ }^{1}$}

Resumo: O presente artigo tem como área de estudo o Direito Processual Civil, sendo que a pesquisa possui como objetivo a análise da Tutela de Evidência prevista no Novo Código de Processo Civil. Sob essa perspectiva, o trabalho está direcionado, predominantemente, em doutrina, que aborda as principais disposições gerais aplicáveis às Tutelas Provisórias e, em seguida, especificamente, ao tratamento que é dado à Tutela Provisória de Evidência, observando-se a nova sistemática processual civil. Ainda assim, a celeridade processual, a razoável duração do processo e a eficiência, são princípios que buscam dar efetividade aos comandos judiciais, para que seja possível a prestação da tutela jurisdicional que satisfaça o interesse das partes. Nesta ótica, as Tutelas Provisórias previstas no Novo Código de Processo Civil possuem como objetivo a entrega do bem da vida em tempo, já que a demora natural da tramitação de um processo pode, em determinados casos, inviabilizar a entrega da tutela jurisdicional invocada a contento das partes. Pretende-se, com o presente trabalho, a ampliação dos estudos sobre o instituto da Tutela Provisória de Evidência, não tendo por finalidade esgotar todos os aspectos nesse âmbito.

Palavras-chave: Tutelas provisórias. Tutela de evidência. Novo código de processo civil.

Abstract: This article focuses on the field of Civil Procedure Law, and the research objectives the analysis of the Evidence Guardianship provided for in the New Code of Civil Procedure. From this perspective, the research approaches mainly the doctrine, which addresses the main general provisions applicable to Provisional Guardianship and, then, specifically, the treatment that is given to Provisional Evidence Guardianship, observing the New Code of Civil Procedure. Even so, the promptness, the reasonable du-

1 Especialista em Direito Público pela Fundação Universidade Regional de Blumenau (FURB). Aluna concluinte da Escola Superior da Magistratura do Estado de Santa Catarina (Esmesc). Graduada em Direito pela Universidade do Sul de Santa Catarina (Unisul). Residente Judicial na $1^{\text {a }}$ Vara Cível do Fórum Distrital do Continente/ Florianópolis. E-mail: scheidt_1@yahoo.com.br 
ration of the process and its efficiency are principles that seek to give effectiveness to judicial commands allowing the legal protection to meet the interests of the parties. In this perspective, the Provisional Guardianship provided for in the new code of Civil Procedure have as goal the delivery of goods of life in time, since the natural delay handling of a process may, in certain cases, derail the judicial protection claimed to satisfy the parties. It is proposed with this work, the extension of the studies about the Institute of Provisional Guardianship of Evidence, with no intention to exhaust all aspects in this context.

Keywords: Provisional guardianship. Evidence guardianship. New code of civil procedure.

\section{INTRODUÇÃO}

A Norma Processual Civil brasileira criou, ao longo do tempo, mecanismos para que fosse possível a prestação da tutela jurisdicional por toda sua extensão, vez que, dia a dia, o número de ações que são ajuizadas vem aumentando.

Por sua vez, o Legislador garantiu à sociedade que, uma vez provocado o Poder Judiciário, caberá a este a análise da lide travada em tempo razoável e com observância à celeridade processual, disposições estas anotadas na Lei Maior.

Portanto, a edição da Lei $n^{\circ}$ 13.105/2015 trouxe importantes mudanças no ramo do Direito Processual Civil, entre as quais a unificação das Tutelas Cautelares e das Tutelas Antecipadas em um único livro, denominado "Da Tutela Provisória", que foi dividida em Tutelas de Urgência e Tutelas de Evidência, visando, justamente, a entrega do bem da vida a tempo.

No presente trabalho, a primeira parte desenvolve os aspectos gerais que dizem respeito à Tutela Provisória de Evidência, tais como a forma e o momento processual que poderá ser pleiteada, a eficácia e o modo de cumprimento no caso de deferimento da medida, as nuances em face da provisoriedade desta decisão, bem como a competência para a análise do pedido.

Em contrapartida, no segundo momento, buscar-se-á a conceituação, caracterização, bem como o apontamento acer- 
ca das situações em que se permite a realização do pedido da Tutela de Evidência, dentro da perspectiva apresentada pela Lei ${ }^{\circ} 13.105 / 2015$.

\section{DISPOSIÇÕES GERAIS APLICÁVEIS ÀS TUTELAS DE EVIDÊNCIA}

A Legislação Processual Civil brasileira trazia as Tutelas Antecipadas e as Tutelas Cautelares como formas de permitir aos jurisdicionados o resguardo do bem da vida discutido na relação processual a ser proposta, ou ainda, no curso do processo judicial.

A Lei $n^{\circ} 5.869 / 1973$, que instituiu o Código de Processo Civil anterior, trouxe as Tutelas Antecipadas (art. 273 da Lei ${ }^{\circ}$ 5.869/1973) e as Tutelas Cautelares (art. 796 e seguintes da Lei $n^{0}$ 5.869/1973), em seções distintas. Com a aprovação da nova sistemática do Código de Direito Processual Civil, tais institutos foram unificados, pois passaram a ser tratados em segmento próprio, constantes no livro V, denominado Tutela Provisória.

As Tutelas Provisórias são concedidas pelo Julgador mediante percepção sucinta e rasa dos fatos trazidos e do direito invocado, ou seja, sem o aprofundamento acerca das provas do direito reclamado pela parte. Dessa forma, pode-se dizer que o Magistrado, ao conceder, ou denegar a Tutela Provisória, utiliza-se da cognição sumária, podendo se fundamentar na Urgência e na Evidência, nos termos do caput do art. 294 do CPC, sendo a última, objeto de aprofundamento do presente trabalho.

\subsection{Forma e momento processual do pedido}

Quanto ao momento em que o pedido da Tutela Provisória deve ser feito, observa-se que,enquanto a Tutela de Urgência pode ser requerida em caráter antecedente ou incidente, a Tutela de Evidência só pode ser requerida em caráter incidental 
(art. 294, parágrafo único, CPC). Esta diferença se dá em face da inexistência de urgência existente na Tutela de Evidência; logo, junto ao pedido principal virá o requerimento para sua concessão.

Assim sendo, a técnica antecipatória (pedido feito em liminar) também é admitida, vez que :

[...] tem justamente por função distribuir de forma isonômica o ônus do tempo no processo. Para tanto, fundamenta-se, ora na urgência, ora na evidência do direito postulado em juízo (art. 294). A "tutela provisória de urgência" pode ser "cautelar ou antecipada" (isto é, satisfativa, art. 294, parágrafo único), ao passo que a tutela da evidência é sempre satisfativa. (MARINONI; ARENHART; MITIDIERO, 2015, p. 233).

A Tutela Antecipatória, deste modo, tem por escopo adiantar o provimento final, objeto do processo principal, apreciando-se initio litis o mérito do pedido e antecipando seus efeitos, ou seja, de cunho exauriente, embora reversível. Assim, antes mesmo da decisão de mérito, no todo ou em parte, aplicam-se os efeitos práticos de uma sentença, exigindo o conhecimento de mérito pré-constituído pela parte. A providência antecipatória está condicionada à confirmação pela sentença terminativa de mérito.

$\mathrm{Na}$ antecipação de tutela não existe autonomia, haja vista que a decisão interlocutória está intimamente vinculada a um pedido, que procura ser antecipado.

Dessa forma, aTutela Antecipada apresentada no contexto das disposições gerais das Tutelas Provisórias de Evidência é aquela em que se exige prova inequívoca, na qual o Julgador se convença da verossimilhança das alegações trazidas pela parte, acrescida da caracterização do abuso de direito de defesa ou do manifesto propósito protelatório do réu.

Em vista disso, em mera situação de evidência (Tutela Provisória de Evidência), o tempo indispensável para que se ob- 
tenha a tutela definitiva não deve ser suportado pelo titular do direito, assentado em afirmações, de fato, comprovadas, razão pela qual se admite a forma antecipada.

Destaca-se que, quando a Tutela Provisória for requerida em caráter incidental, ou seja, durante o deslinde da ação principal, tal requerimento independerá do pagamento de custas (art. 295, CPC).

Ainda, o Código de Processo Civil trouxe que se conservará a eficácia da Tutela Provisória de Evidência concedida enquanto pendente o processo, ressalvando, todavia, que a medida poderá ser revogada ou modificada em qualquer tempo; por isso, mutável (art. 296, CPC).

Nesse ponto, cumpre destacar que a concessão das Tutelas Provisórias de Evidência possui caráter precário, admitindo-se a modificação da decisão anteriormente proferida. Contudo, a alteração da decisão que a concedeu, precisa advir da modificação dos fatos até então apresentados, ou até mesmo, da rejeição final do pedido. No caso da alteração dos fatos, antes de se proferir a decisão final, é imprescindível que algum dos pressupostos que autorizou sua concessão tenha desaparecido.

Assim, enquanto se discute o direito pleiteado, regra geral, a Tutela Provisória concedida manterá sua eficácia, podendo, todavia, sofrer modificação ou revogação a qualquer tempo. Dessa forma, a nova Norma Processual enuncia a manutenção da Tutela Provisória de Evidência concedida no curso do processo, até mesmo no caso de interrupção na sua regular tramitação.

\subsection{Recursos cabíveis}

A decisão que revoga, modifica ou concede a Tutela Provisória de Evidência, por ser classificada como decisão interlocutória, poderá ser revista, mediante a interposição do recurso de agravo de instrumento (art. 1.015, I, e seguintes, CPC). 
Destaca-se que as decisões interlocutórias, via de regra, serão objeto de impugnação, ou no bojo da apelação, em capítulo preliminar próprio, ou nas contrarrazões. A nova sistemática, portanto, torna absolutamente excepcionais as hipóteses de interposição de recurso de agravo de instrumento em face de decisões interlocutórias, determinando que sua impugnação se dê, em regra, no recurso de apelação ou nas contrarrazões a este apresentadas, nos termos do art. 1.009, $\S 1^{\circ}$, CPC.

Denota-se a amplitude da interposição do recurso de agravo de instrumento, pois a Legislação permitiu que, em quaisquer dos casos, em se tratando das Tutelas Provisórias, a parte prejudicada poderá se utilizar de tal mecanismo (art. 1.015, I, CPC).

Por sua vez, caso haja alteração na decisão que concedeu ou denegou a Tutela Provisória de Evidência, quando da prolação da sentença, a parte prejudicada poderá se valer da interposição do recurso de apelação, cuja decisão produzirá efeitos imediatos, pois este reclamo será dotado apenas do efeito devolutivo (art. 1.012, $\S 1^{\circ}, \mathrm{V}, \mathrm{CPC}$ ).

Sobre o recurso de apelação, importante mencionar que, como regra geral, prevalece o seu recebimento no efeito suspensivo, o que não releva no caso de decisão queconfirma, concede ou revoga a Tutela Provisória de Evidência, pois esta surtirá efeitos práticos, ainda que pendente de recurso. No entanto, há previsão de que "a eficácia da sentença poderá ser suspensa pelo relator, se o apelante demonstrar a probabilidade de provimento do recurso ou sendo relevante a fundamentação, houver risco de

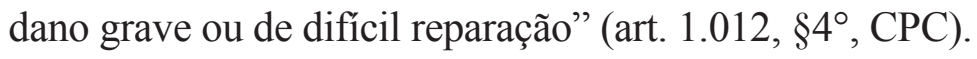

Nessa situação, poderá se suspender a decisão acerca da Tutela Provisória, desde que preenchidas as duas condições distintas. A primeira trata da demonstração da probabilidade de recurso que necessita de evidência de êxito recursal (espécie de Tutela de Evidência) e, a segunda, consiste na típica pretensão de Tutela de Urgência, pois se exige, para suspen- 
são da eficácia da sentença, a demonstração conjunta da relevância da fundamentação (vale dizer, o quão relevante é a pretensão recursal, algo assemelhado à aparência do bom direito) e o risco de que, se for passível de cumprimento desde a sua publicação, a sentença poderá gerar dano irreparável, grave ou de difícil reparação (art. 1.012, $4^{\circ}, \mathrm{CPC}$ ).

Permitiu-se dessa forma, que a parte prejudicada com a decisão a respeito da Tutela Provisória possa requerer o efeito suspensivo da apelação recebida apenas no efeito devolutivo. Nesse caso, o pedido será dirigido ao Tribunal, se realizado entre a interposição da apelação e a sua distribuição, sendo que o relator, que receber este pedido, tornar-se-á prevento para analisar a apelação que virá em momento posterior, ou ao relator que já é competente para analisar a apelação distribuída (art. 1.012, $\S 3^{\circ}, \mathrm{CPC}$ ).

\subsection{Motivação da decisão}

O Código de Processo Civil expressamente estabeleceu que, a decisão que analisar a Tutela de Evidência, deverá apresentar a motivação de forma clara e precisa, conforme disposto no art. 298. Dessa forma, a Legislação impõe ao Julgador o dever de apresentar, sem obscuridade e indeterminação, os aspectos que formaram o convencimento adotado.

Destaca-se que, embora não houvesse esta previsão legal, CRFB/1988, no seu art. 93, IX,já determinava que o julgamento proferido pelos órgãos que compõem o Poder Judiciário deverá ser fundamentado, sob pena de ser considerada nula a decisão. Nessa linha, todas as decisões que não sejam de simples impulso processual, caberá ao Magistrado fundamentar sua decisão.

\subsection{Efeitos e o cumprimento da decisão de concessão da tutela provisória de evidência}

O Código de Processo Civil elucida que as Tutelas Pro- 
visórias de Evidência não terão sua eficácia sustada na eventualidade de suspensão do processo (parágrafo único do art. 296, CPC), hipóteses previstas no art. 313, CPC. Destarte, a nova Legislação traz que o processo será suspenso: quando as partes assim convencionarem, quando arguida a suspeição ou impedimento, quando admitido o incidente de resolução de demandas repetitivas, quando falecer ou se perder a capacidade processual de qualquer das partes, de seu representante legal ou de seu procurador, entre outros casos.

Por conseguinte, no período em que o processo ficar suspenso, em se tratando de hipótese em que a Tutela Provisória for concedida, esta medida manterá sua eficácia durante o período de suspensão, pois caso contrário, a parte poderia ser prejudicada em face de situações que o polo adverso tenha dado azo, caracterizando-se a mera protelação, adiando-se, por isso, a prestação jurisdicional.

No que concerne aos efeitos gerados pela concessão da Tutela Provisória, sabe-se que o requerente almeja sua aplicabilidade imediata e a consequente mudança no plano fático, para que assim, seja verificada a efetividade dos direitos reclamados, os quais somente seriam analisados quando da prolação da sentença que entregará a tutela definitiva.

Por esse motivo, deu-se liberdade ao Julgador para que, quando for conceder a Tutela Provisória, sejam utilizadas as medidas que considerar mais adequadas, a fim de que se alcance o objetivoda tutela requerida (art. 297, CPC). Constata-se que o Legislador não especificou quais medidas deverão ser utilizadas para o reclamante ver o seu direito colocado em prática. Assim, a discricionariedade do Magistrado permite que, em cada caso, seja possível aferir qual medida é a mais adequada e eficaz.

Além disso, em se tratando de efetivação da tutela concedida, a Legislação prevê a aplicação das regras do cumprimen- 
to provisório de sentença (parágrafo único do art. 297 e art. $1.012, \S 2^{\circ}$, ambos do CPC).

A Execução, ainda que provisória, tende a buscar a satisfação do credor. Nesse caso, em se tratando de execução em que há, no polo passivo, número singular ou pequeno de credores, "a agressão patrimonial fica restrita à parcela necessária para a satisfação do crédito" (THEODORO JÚNIOR, 2011, p. 127).

Quanto ao cumprimento de sentença (arts. 520 a 522, CPC), o Código de Processo Civil estabelece que a parte que deseja executar a Tutela Provisória seja responsabilizada, podendo ser obrigada a indenizar o polo adversa, se trouxer prejuízos com a efetivação da medida. Vale realçar que se trata de responsabilidade objetiva, ou seja, a responsabilidade correrá por conta e risco de quem teve a Tutela Provisória concedida em seu favor (art. 520, I, CPC).

Ademais, se o objeto da Tutela Provisória de Evidência tratar das hipóteses seguintes: levantamento de valores; transferência de posse ou alienação de propriedade ou outro direito real; possibilidade de resultar em grave dano ao executado-caberá ao exequente prestar caução suficiente e idônea, que será arbitrada pelo Magistrado e prestada nos próprios autos (art. 520, IV, CPC).

Ainda, conforme for o pronunciamento no que tange a irresignação manifestada, a execução provisória se extinguirá, passando a ser definitiva. Entretanto, em havendo reforma na decisão que deu origem à execução provisória, a execução seguirá até sua satisfação (provimento com reforma parcial) ou o exequente deverá retornar ao status quo (provimento com reforma total).

Neste último caso, caberá ao exequente restituir eventuais valores cobrados, corrigidos monetariamente, ou ainda, liberar bens penhorados e, em último caso, indenizar a parte adversa 
por eventuais danos, não passíveis de restituição, ou pelos danos causados em face da execução provisória.

O cumprimento provisório de sentença é viável, desde que não seja atribuído efeito suspensivo ao recurso, ou enquanto o efeito suspensivo não the for agregado ao recurso.

Assim, o cumprimento provisório de sentença difere das regras relativas ao cumprimento definitivo de sentença, em outros dois casos: (i) na responsabilidade (objetiva) do exequente pelos danos que sua iniciativa puder causar, no caso de provimento de recurso interposto pela parte contrária, na exata proporção em que seja modificado o título executivo que fundamenta a prática dos atos executivos, correndo por conta e risco exclusivo do exequente (art. 520, I e II, CPC) e (ii) na circunstância de a satisfação do exequente depender, de regra, de caução suficiente e idônea (WAMBIER et al., 2015, p. 1341-1342).

No caso de cumprimento provisório de sentença o devedor deverá comparecer, no prazo de 15 dias após a intimação, e depositar o valor da dívida, visando, dessa forma, não incorrer na multa de $10 \%$ sobre o valor. Cinge-se que tal ato não poderá ser compreendido como incompatível com o recurso interposto pelo devedor (art. 520, $\S 3^{\circ}, \mathrm{CPC}$ ).

É imprescindível mencionar que o depósito não consiste na representação do pagamento voluntário da dívida, situação prevista em outra oportunidade na Legislação (art. 526). Nesta, o devedor tem a iniciativa, antes mesmo de iniciada a execução, de entregar o pagamento do valor que entende devido.

Ademais, o depósito da coisa ou do dinheiro, na primeira oportunidade, traz como consequências o direito de recorrer e o afastamento de eventual multa, no caso de não provimento dos recursos do devedor; por outro lado, na segunda oportunidade, a intenção é o pagamento da dívida que entende devida, mesmo que parcial (valor incontroverso). 
Enfim, cumpre anotar que é cabível o recurso de agravo de instrumento a respeito da decisão proferida em cumprimento provisório de sentença, consoante disposição contida no art. 1.015, parágrafo único, CPC.

\subsection{Competência}

Quanto à competência para a análise das Tutelas Provisórias de Evidência, a Legislação estabelece que caberá ao Magistrado da causa decidir (art. 299, CPC).

Existe a hipótese de o processo já ter sido analisado em primeiro grau e, da sentença proferida, interpôs-se recurso. Desse modo, o processo será encaminhado àInstância Superior para análise em Colegiado. Nesse lapso temporal, poderá ocorrer que os pressupostos da Tutela Provisória de Evidência sejam preenchidos após a prolação da sentença. Tratar-se-á de Tutela Provisória incidental de competência do Tribunal.

Assim sendo, no caso de competência originária dos Tribunais ou enquanto houver recurso pendente de análise, o pleito da Tutela Provisória de Evidência deverá ser encaminhado ao órgão jurisdicional que possui a competência para julgar o mérito da causa (parágrafo único do art. 299, CPC).

Apresentados e vencidos os aspectos gerais dispostos no Novo Código de Processo Civil aplicáveis às Tutelas Provisórias, passa-se à análise específica sobre as Tutelas Provisórias de Evidência.

\section{TUTELA PROVISÓRIA DE EVIDÊNCIA}

Conforme visto, o Legislador, ao tratar das Tutelas Provisórias, dividiu-as em Tutelas de Urgência e Tutelas de Evidência. Ainda, considerando a delimitação apontada no início do presente trabalho, será dado continuidade aos estudos relativos às Tutelas Provisórias de Evidência. 


\subsection{Conceito}

Existem situações em que o direito invocado pela parte se mostra com um grau de probabilidade tão elevado, que se torna evidente. Diante dessas situações, "não se conceber um tratamento diferenciado, pode ser considerado uma espécie de denegação de justiça, pois, certamente, haverá o sacrifício do autor diante do tempo do processo". (FUX, 1996, p. 321).

Assim, quando se fala em Tutela de Evidência, deve-se compreender como a tutela de um direito que, de tão claro, impele uma rápida proteção jurisdicional, hipótese em que, "embora não haja risco de dano à esfera jurídica do autor (grau nenhum) ou embora este risco seja desprezível (grau mínimo), o Juiz concede a tutela em face da certeza ou quase-certeza do direito alegado (grau máximo)". (MEDINA, 2015, p. 501).

Dessa forma, nos termos da Lei $\mathrm{n}^{0} 13.105 / 2015$, a qual instituiu o Novo Código de Processo Civil, que entrou em vigor em março de 2016, o Legislador procurou caracterizar a evidência do direito postulado em juízo capaz de justificar a prestação da Tutela Provisória a partir de quatro situações, consagradas no art. 311, CPC.

Há duas modalidades de Tutela Provisória de Evidência: a) punitiva (inciso I, do art. 311, CPC) e, b) documentada (incisos I a IV, art. 311, CPC) (DIDIER; OLIVEIRA; BRAGA, 2015, p. 619-620).

Analisando-se as situações mencionadas, verifica-se a existência de identidade entre elas, pois em todas há defesa inconsistente. Nesse sentido, pode-se afirmar que a Tutela Provisória de Evidência será concedida antecipadamente em face da defesa apresentada de maneira inconsistente ou de que provavelmente assim o será.

Cumpre obtemperar que, nos casos em que o Magistrado decide antes mesmo de ouvir a parte adversa,não há violação 
da garantia do contraditório, pois a concessão se justifica pelo perigo existente na Tutela Provisória liminar. Isso porque há uma ponderação legislativa entre a efetividade e o contraditório, sendo este preservado para momento posterior.Logo, nos casos de Tutela Provisória de Evidência, muito embora não haja perigo, a alta probabilidade de êxito da demanda é reconhecida como apta a mitigar o contraditório, postecipando-se da mesma maneira (DIDIER JÚNIOR, 2015, p. 83).

Ao se analisar a questão do contraditório, entende-se que ele poderá ser diferido quando nafalta de forma de se tutelar, de maneira efetiva, o direito do autor, não se retirandodo interessado a possibilidade de fazer instaurar um juízo ordinário, com a garantia de um contraditório amplo.

Antes de explanar as situações apresentadas pelo Legislador, convém anotar que estas não se confundem com aquelas em que o Magistrado julga antecipadamente o mérito, vez que as Tutelas de Evidência pautam-se em cognição sumária e, portanto, traduzem-se em uma decisão revogável e provisória (enquanto que as sentenças de julgamentos antecipados são definitivas) (WAMBIER et al., 2015, p. 523).

Neste ponto, é de destacar que as decisões antecipatórias de mérito extinguem o processo com a apreciação da lide, impugnável pelo recurso de apelação e sujeitas à coisa julgada material, ao passo que, na Tutela de Evidência, há decisão interlocutória, impugnável por agravo de instrumento e não sujeita à coisa julgada material.

Sendo assim, o CPC veio com uma estrutura diferenciada para as Tutelas de Evidência, já que se permite ao autor, desde que demonstrada a evidência do seu direito, a antecipação dos efeitos da tutela final ou mesmo a concessão de tutela conservativa.

A concessão da Tutela de Evidência deve também se dar 
nos casos em que as alegações da parte se revelem de juridicidade ostensiva, independentemente de periculum in mora por não haver razão relevante para a espera, até porque, via de regra, a demora do processo é apta a gerar agravamento do dano.

Assim,

O que se pretende com a instituição da Tutela de Evidência é, na verdade, uma racionalização econômica do sistema existente, com plena valorização da rápida e eficaz prestação jurisdicional, evitando o prolongamento da demanda quando o princípio da economia processual recomenda, diante de circunstâncias expressamente discriminadas em lei, a entrega antecipada daquilo que se pretendia ao final do procedimento de cognição exauriente. (SOUZA, 2014, p. 157).

Em conformidade à introdução do presente trabalho, com a possibilidade de se conceder a Tutela de Evidência, está-se respeitando os princípios da celeridade processual e da razoável duração do processo, pois, se não,haveria impedimentoao exercício do direito que a parte possui.

Verifica-se, assim, que a Tutela Provisória de Evidência foi criada para assegurar aos litigantes o princípio da igualdade e da razoável duração do processo, já que somente será concedida se preenchida alguma das quatro hipóteses legais, as quais retratam grandes chances de reconhecimento do direito reclamado ou, ainda, quando um dos polos busca criar empecilhos para prejudicar o outro.

A decisão proferida pelo Estado-Juizprecisa estar revestida de indícios fortes e claros do direito reclamado, pois ao se conceder a tutela, inevitavelmente, estar-se-á prejudicando a outra parte. Embora seja possível a retificação da decisão, essa possibilidade deve ser remota ou sequer existir. Por outro lado, em existindo essa possibilidade, deve-se sopesar que eventual erro na decisão seja menos oneroso que a não concessão da medida.

O CPC, portanto, no livro "Da Tutela Provisória de Evi- 
dência”, elucida quatro situações em que poderá ser concedida, as quais serão analisadas a seguir.

\subsection{Abuso do direito de defesa ou manifesto protelatório da parte}

$\mathrm{O}$ art. 311, I, CPC, deve ser compreendido como Norma aberta que permite a antecipação de tutela sem urgência em toda e qualquer situação em que a defesa do réu se mostre frágil diante da robustez dos argumentos do autor e da prova por ele produzida na petição inicial, ou seja, poderá ser deferida quando houver defesa inconsistente. (MITIDIERO, 2015, p. 796).

Logo, entende-se que esta previsão é uma espécie de punição, pois funciona como sanção para apenar aquele que age de má-fé, sobretudo, aquele que tenciona comprometer a celeridade processual, a razoável duração do processo e a lealdade, princípios estes que regem o Direito Processual Civil brasileiro.

Além de punir, seu objetivo é também garantir a igualdade substancial entre as partes, impondo o peso do tempo necessário para a investigação e cognição judicial sobre aquele que abusou do direito de defesa e, logo, de menor evidência (ou probabilidade), o que acaba por não contribuir para o bom andamento do feito.O pressuposto único e necessário para a concessão dessa tutela antecipatória é que a parte diversa "exerça o seu direito de defesa de maneira não séria, inconsistente". (DIDIER; BRAGA; OLIVEIRA, 2015, p. 620).

A defesa, nessa linha, pode ser excessiva, inadequada, abusiva, entre outras formas, com o propósito de frustrar ou atrasar a prestação da tutela jurisdicional.

É interessante observar que o réu pode apresentar defesa técnica adequada e mesmo assim abusar do direito de defesa, que deve ser lido consoante o princípio da ampla defesa, abarcando não só as peças confeccionadas a esse título (contestação, reconvenção etc) como também a 
conduta do réu na defesa dos seus interesses (WAMBIER et al., 2015, p. 524).

Assim, a defesa protelatória do réu permite destacar mais, o direitoque o autor reclama, desse modo, evidenciando maior probabilidade de vitória da pretensão deste.

Insta ressaltar que:

[...] o abuso do direito de defesa é mais perverso quando o autor depende economicamente do bem da vida perseguido, hipótese em que a protelação acentua a desigualdade entre as partes, transformando o tão decantado princípio da igualdade em uma abstração irritante. Poucos se dão conta que, em regra, o autor pretende uma modificação da realidade empírica e o réu deseja a manutenção do status quo. Esta percepção, até banal, da verdadeira realidade do processo civil, é fundamental para a compreensão da problemática do tempo do processo ou do conflito entre o direito à tempestividade da tutela jurisdicional e o direito à cognição definitiva. Em qualquer processo civil há uma situação concreta, uma luta por um bem da vida, que incide de modo radicalmente oposto sobre as posições das partes. A disputa pelo bem da vida perseguido pelo autor, justamente porque demanda tempo, somente pode prejudicar o autor que tem razão e, beneficiar o réu que não tem. Em um processo condenatório, a demora na obtenção do bem significa a sua preservação no patrimônio do réu. Quanto maior for a demora do processo, maior será o dano imposto ao autor e, por consequência, maior será o benefício conferido ao réu [...] A técnica antecipatória nada mais é do que uma técnica de distribuição do ônus do tempo do processo. (MARINONI, 2002, p. 191).

No caso em tela, o abuso do direito de defesa ou manifesto propósito protelatório corroboram o direito que existe em determinada situação. Todavia, a redação constante no art. 311, I, CPC é criticada, vez que

A má-técnica da redação [...] não deve conduzir ao entendimento de que algo inverossímil, afirmado pelo autor da ação, seja considerado evidente, tão só pelo fato de o réu ter 
abusado do direito de defesa. O abuso ou a prática de atos protelatórios poderão conduzir à condenação por litigância de má-fé [...] mas não necessariamente, à concessão de Tutela de Evidência. (MEDINA, 2015, p. 501).

Dessarte, esta primeira hipótese configura a intenção da parte em prorrogar determinada situação sem haver, de fato, a necessidade para tanto, prejudicando, com isso, a parte adversa que compõe a lide, bem como,quando há excesso ou desrespeito na externação do direito de defesa. Nesse caso, o demandado não se utiliza do contraditório e da ampla defesa para defender um direito seu; ao contrário, utiliza-se dos meios processuais para se desvirtuar dessa finalidade.

Tais situações comprometem a boa-fé processual dos litigantes, bem como a celeridade processual. Denota-se, nesses casos, que se fere a finalidade dos atos praticados, rasgando-se a efetividade da prestação da tutela jurisdicional.

\subsection{Precedentes}

O preceituado no art. 311, II, do CPC, demonstra que a inconsistência na defesa do réu se encontra no fato de o direito do autor estar fundamentado em precedente do Supremo Tribunal Federal (STF) ou no Superior Tribunal de Justiça (STJ) ou em jurisprudência formada nos Tribunais de Justiça e nos Tribunais Regionais Federais em sede de incidente de resolução de demandas repetitivas.

Destaca-se que tais precedentes podem ou não ser oriundos de casos repetitivos e, também, podem não ter adequadamente suas razões retratadas em súmulas vinculantes.

Sobre essa hipótese, a concessão da Tutela de Evidência independe da atitude do réu, tendo em vista que há necessidade de preenchimento de dois requisitos, a saber: a) o fato esteja comprovado por meio de documentos apresentados pelo autor e, b) a questão trazida à discussão envolva conteúdo já paci- 
ficado, seja por meio de edição de súmula vinculante ou pelo julgamento de casos repetitivos.

Verifica-se então, que não pode haver controvérsia na jurisprudência sobre a procedência do que pede o autor. Por conseguinte, é necessário conferir se a orientação jurisprudencial se adapta ao caso concreto.

Essa segunda hipótese, dá-senos casos em que a alegação fática puder ser comprovada estritamente por meio de documentos, o que implica dizer que provas documentais são suficientes para demonstrar que os fatos noticiados pelo interessado são verdadeiros. É relevante que a prova necessita ser documental, bem como, que recaia sobre o fato constitutivo do direito reclamado. No entanto, não há a necessidade desta prova ser documental, se os fatos trazidos ao juízo forem notórios, confessados pelo polo adverso, incontroversos ou presumidos (art. 374, CPC).

O CPCdispõe que, a sentença possui como elemento essencial os fundamentos que conduziram o Magistrado a tomar determinado posicionamento (art. 489, II, CPC). A respeito disso, há de observar que o Legislador deixou expresso que uma decisão não se fundamenta com mera invocação de precedente ou enunciado de súmula vinculante, devendo haver identificação dos fundamentos, sendo apontado que o caso se adequa aos fundamentos da decisão invocada (art. 489, § $1^{\circ}, \mathrm{V}$, CPC). Nesse sentido, é necessário que o Magistrado apresente as semelhanças entre o caso prático sob sua condução e o precedente invocado.

Do mesmo modo, no caso de não acolhimento da pretensão do autor, deverá o Magistrado demonstrar o fato apresentado e a superação do entendimento (art. 489, $\S 1^{\circ}, \mathrm{VI}, \mathrm{CPC}$ ).

Quanto às súmulas vinculantes, são tratadas decisões reiteradas no âmbito da matéria constitucional, proferidas pela 
Corte Máxima, cujo entendimento vinculará as Instâncias Inferiores. São precedentes que devem obrigatoriamente ser respeitados, haja vista o amplo debate concernente ao tema. Nessa perspectiva, a parte possui grande probabilidade de êxito na demanda proposta e, em contrapartida, a improbabilidade de sucesso milita em desfavor da parte contrária.

Ante essas situações, não deve o polo ativo suportar o ônus advindo da demora processual que, muito embora possa não se revestir de atos protelatórios ensejados pelo réu, possui a decorrência de um lapso temporal natural para a formação de convencimento pelo Magistrado, o qual deverá observar os fatos repetitivos e as súmulas vinculantes.

Passa-se, agora, à análise da terceira situação de cabimento da Tutela Provisória de Evidência.

\subsection{Contrato de depósito}

Esta hipótese diz respeito "ao pedido reipersecutório fundado em prova documental adequada do contrato de depósito, caso em que será decretada a ordem de entrega do objeto custodiado" (art. 311, III, CPC).

A modalidade contratual mencionada pelo Legislador está prevista no Código Civil, no art. 627 e seguintes,em que é estabelecida a obrigação do depositário guardar e conservar o bem como se seu fosse e, obrigando-se também, a restituí-lo ao depositante, com seus respectivos frutos, se houverem.

Essa hipótese veio para tomar o lugar do procedimento especial de depósito previsto no Código precedente, uma vez que antes também caberia ao depositante ingressar com ação de depósito, para compelir o depositário a entregar o bem depositado.

Atualmente, com as disposições apresentadas pelo novo CPC, foi eliminado este procedimento específico, pois estando devidamente provado o depósito,mediante apresentação da 
prova documental do contrato de depósito, restará ao Magistrado determinar a entrega da coisa depositada.

No caso de não cumprimento da decisão, poderá o Magistrado se valer da aplicação de multa diária. Essa possibilidade reafirma o poder geral de cautela, conforme caput do art. 297, CPC, caso verifique que a medida dessa obrigação possa ser efetivada de outro modo.

\subsection{Prova contrária}

Por último, a quartahipótese traduz a ideia de que o tempo para produção da prova deve ser suportado pelo réu, e não pelo autor, o qual já se desincumbiu de seu ônus probatório documentalmente.

$\mathrm{O}$ art. 311, IV, CPC preceitua que "quando a petição inicial for instruída com prova documental suficiente dos fatos constitutivos do direito do autor, a que o réu não oponha prova capaz de gerar dúvida razoável", é possível a concessão da Tutela de Evidência. (BRASIL, 2015).

Nesse caso, é exigido ao autor a entrega de prova documental suficiente para comprovar os fatos que alega (fatos constitutivos do seu direito), bem como que réu se abstenhade apresentar prova capaz de gerar dúvida razoável sobre aquilo que o autor colocou em discussão. Notadamente, o réu não conseguirá impedir, modificar ou extinguir o direito reclamado pelo autor, ônus que lhe incumbe (art. 373, II, CPC).

Logo, tem que ser ponderada a possibilidade de concessão da Tutela de Evidência quando o autor alega e traz prova do fato constitutivo do seu direito, sendo que o réu opõe defesa indireta sem oferecer prova documental, protestando pela produção de provas oral e prova pericial (MITIDIERO, 2015, p. 797).

Basta, nessa hipótese, que não haja aptidão para demover o grau de certeza que a prova documental juntada pelo autor 
trouxe. Podemos dizer que a prova juntada aos autos pelo autor já ostentava a concessão de um direito muito provável que, em face da prova debilitada apresentada pelo réu, passou a "adquirir mais veemência, sendo considerada 'evidente' pela lei processual". (MEDINA, 2015, p. 502).

É importante destacar que a Legislação aponta o segundo e o terceiro caso como situações em que a Tutela Provisória de Evidência poderá ser concedida sem a oitiva da parte adversa, ou seja, a parte adversa pode ter uma decisão que caracterize a concessão da Tutela de Evidência, sem ao menos, haver o exercício do contraditório. Trata-se de decisão proferida liminarmente (art. 311, parágrafo único, CPC).

\subsection{Momento para a concessão}

A Tutela de Evidência depende do cotejo entre as posições jurídicas do autor e do réu no processo, pelo fato de a Tutela de Evidência estar ligada ao oferecimento de defesa que seja inconsistente, o que pressupõe o exercício do direito de defesa.

Dentre as quatro situações, duas têm a presunção de defesa infundada (art. 311, II e III, CPC). Por isso, cabe a concessão da Tutela de Evidência liminarmente, nos termos do disposto no art. 311, parágrafo único, CPC. Por conseguinte, nos demais casos, a concessão da Tutela de Evidência somente poderá se dar em momento posterior à contestação.

Consequentemente, apenas é permitido ao Magistrado a decisão liminar, isto é, sem a prévia oitiva do requerido, nos casos em que houver prova exclusivamente documental apresentada pelo autor, acompanhada de tese firmada em casos repetitivos ou súmula vinculante, ou quando se tratar de pedido reipersecutório, desde que fundado em prova consistente no contrato de depósito.

Por exclusão, as outras duas hipóteses constantes no inciso 
I e IV do art. 311, CPC, quais sejam: defesa abusiva/procrastinatória e defesa inconsistente, respectivamente, somente poderá haver concessão de Tutela de Evidência após a análise da defesa apresentada pelo polo passivo.

\section{CONCLUSÃO}

Ao longo do presente trabalho, é verificado que a Tutela Antecipada existente na sistemática Processual Civil de 1973 foi substituída pela Tutela Provisória de Evidência, que antecipa a entrega do bem da vida, sempre na forma incidental, uma vez que independe da demonstração do perigo de dano ou do risco ao resultado útil ao processo.

Foi justificada a existência das Tutelas Provisórias em face da demora na prestação jurisdicional inerente à tramitação do processo até o seu julgamento, sendo que este lapso temporal pode ocasionar prejuízos à parte que possui o direito que pretende ver declarado em seu favor.

No campo das Tutelas Provisórias de Evidência, foram analisadas as disposições gerais que lhes são aplicáveis, verificando-se a provisoriedade da decisão, uma vez que foi proferida mediante cognição sumária dos fatos e das provas constantes nos autos. Pelo que, é viável a alteração da decisão proferida.

No presente trabalho, procurou-se analisar os principais apontamentos trazidos pelo Legislador, os quais dizem respeito à verificação de abuso do direito de defesa e de manifesto protelatório, existência de prova documental que demonstre que o direito invocado pela parte encontra-se sob a guarida dos precedentes, pedido reipersecutório em face de contrato de depósito e defesa inconsistente.

Conforme observado, a Tutela Provisória de Evidência tem, em sua essência, os princípios que norteiam a nova sistemática Processual Civil, nos quais o direito se desenvolve na 
busca pela verdade, pelo reconhecimento de evidência deste mesmo direito e, propriamente, pela Justiça.

Por meio da abordagem feita, este instituto visa amenizar a morosidade da Justiça, fomentando a celeridade do processo. Salienta-se que o presente trabalho teve como objetivo ampliar o estudo das Tutelas Provisórias, especificamente, no que tange às Tutelas de Evidência.

\section{REFERENCIAS}

BRASIL.Lei $n^{\circ}$ 13.105/2015.Código de Processo Civil. 2015. Disponível em: $<$ http:// www.planalto.gov.br/ccivil_03/_Ato2015-2018/2015/Lei/L13105.htm>. Acesso em: 29jun. 2016.

BRASIL.Lei $n^{\circ}$ 5.869/1973.Institui o Código de Processo Civil. Disponível em: $<$ http:// www.planalto.gov.br/ccivil_03/leis/L5869.htm>. Acesso em: 29jun. 2016.

BRASIL.Lei $n^{\circ}$ 10.406/2002.Institui o Código Civil. Disponível em: <http://www.planalto.

gov.br/ccivil_03/leis/2002/L10406.htm>. Acesso em: 30 jun. 2016.

BRASIL.Constituição (1988).Constituição da República Federativa do Brasil. 1988. Disponível em:<http://www.planalto.gov.br/ccivil_03/constituicao/constituicaocompilado.

htm>. Acesso em: 29 jun. 2016.

DIDIER JÚNIOR, Fredie. Curso de direito processual civil: introdução ao direito processual civil: parte geral e processo de conhecimento. 17. ed. Salvador: Juspodivm, 2015. v. 2.

DIDIER JÚNIOR, Fredie; BRAGA, Paula Sarno; OLIVEIRA, Rafael Alexandria de. Curso de direito processual civil-v. 2: teoria da prova, direito probatório, decisão, precedente, coisa julgada e tutela provisória.10. ed. Salvador: Juspodivm, 2015.

FUX, Luiz. Tutela de segurança e tutela de evidência. São Paulo: Saraiva, 1996.

LOVATO, Luiz Gustavo; SCHEIDT, Emiliane. O novo código de processo civil gerais aplicáveis às tutelas provisórias. Disponível em: $<$ http://www.portaldeperiodicos. unisul.br/

index.php/U_Fato_Direito/article/view/3597/2568>. Acesso em: 29 jun. 2016.

LOVATO, Luiz Gustavo. Curso de processo civil: tutelas provisórias, juizados especiais e procedimento comum.Florianópolis: Lumen Juris, 2015. v.3.

MARINONI, Luiz Guilherme. A antecipação da tutela. 7. ed. São Paulo: Malheiros, 2002.

MARINONI, Luiz Guilherme; ARENHART, Sérgio Cruz; MITIDIERO, Daniel. $O$ 
novo processo civil. São Paulo: Revista dos Tribunais, 2015.

MEDINA, José Miguel Garcia. Novo código de processo civil comentado. São Paulo: Revista dos Tribunais, 2015.

SOUZA, Arthur César de. Da tutela de evidência e da tutela satisfativa: última parte. Revista de Processo.São Paulo, v. 39, n. 235, set. 2014.

WAMBIER, Teresa Arruda Alvim et al. Breves comentários ao novo código de processo civil. São Paulo: Revista dos Tribunais, 2015.

WAMBIER, Teresa Arruda Alvim et al. Primeiros comentários ao novo código de processo civil: artigo por artigo. São Paulo: Revista dos Tribunais, 2015.

THEODORO JÚNIOR, Humberto. Curso de direito processual civil: processo de execução e cumprimento da sentença, processo cautelar e tutela de urgência. Rio de Janeiro: Forense, 2011. v.2.

Artigo recebido em 25/05/2016

Artigo aprovado em 14/07/2016 